\title{
Consumer Preference and Storage Stability Assessment of Drum Dried- Maltodextrin Added Kunun-gyada Powder
}

\author{
Musa Halilu ${ }^{1}$, Yunusa Bello $\mathrm{M}^{2 *}$ and Hasanah M. Ghazali ${ }^{3}$ \\ ${ }^{1}$ Department of Food Science and Technology, Modibbo Adama University of Technology Yola, Adamawa State, Nigeria \\ ${ }^{2}$ Department of Food Technology, Faculty of Agriculture and Life Science, Federal University Wukari, Taraba State, Nigeria \\ ${ }^{3}$ Department of Food Science, Faculty of Food Science and Technology, Universiti Putra Malaysia, 43400 Serdang, Selangor, \\ Malaysia
}

\author{
Article History \\ Received: 16.08 .2021 \\ Accepted: 20.09 .2021 \\ Published: 16.01.2022 \\ Journal homepage: \\ https://www.easpublisher.com
}

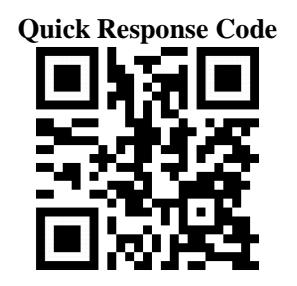

Abstract: Kunun gyada is cereal-based Nigerian porridge produce from cereal flour in combination with groundnut milk. There is the growing popularity of local beverage drinks such as the kunun-gyada, kunun-Zaki, kunun-tsamiya in Nigeria, and thus, this posses great research challenges that require processing improvement from the traditional method of preparation, value addition, and extension of storage life of the products. Research has shown that the product can easily go bad when stored unrefrigerated and even when refrigerated, the product can only be kept for a maximum of four days (Gaffa et al., 2002). Sensory evaluation indicated that the kunun gyada powder was slightly oily to touch. The product was rated low for overall acceptability base on sensory evaluation by consumers under a 5-point hedonic scale. The powder was observed to be oily which might have hurt the panelist overall assessment of the product. Due to this, the kunun gyada powder was modified to contain $5 \%$ maltodextrin and was investigated for consumer acceptability and storage stability. The product was stable during storage, the colour of the maltodextrin-added product was significantly lighter ( $L^{*}$ was $76.31 \%$ ). The viscosity of the product also increased from 15.75 to $17.12 \mathrm{mPa}$.s. The addition of maltodextrin improved the product's overall acceptability significantly from 2.72 to 3.89 based on a five-point Hedonic scale.

Keyword: Kunun-gyada, consumer, storage, dried-maltodextrin.

Copyright (C) 2022 The Author(s): This is an open-access article distributed under the terms of the Creative Commons Attribution 4.0 International License (CC BY-NC 4.0) which permits unrestricted use, distribution, and reproduction in any medium for non-commercial use provided the original author and source are credited.

\section{INTRODUCTION}

Kunun gyada is a Nigerian cereal porridge made with groundnut milk and made from cereal flour. In general, "Kunu" refers to a thin porridge made from cereal flour (rice, millet, maize, Sorghum, etc). Kunungyada is kunu combined with groundnut milk (cereal flour combined with groundnut milk). qukl It is commonly consumed as a breakfast and weaning dish. The manufacture of kunun gyada has traditionally been done on a limited scale, and the product has yet to be properly popularized. According to research, the product is poor in protein and might spoil quickly if not refrigerated. However, if kunun gyada is kept in the refrigerator, it can only be kept for four days.

(Gaffa et al., 2002). Consumers may find a dry powdered kunun-gyada to be handier. Groundnut paste, rice flour, 24 hour germinated soybean flour, and toasted sesame flour were combined in a 60:25:10:5 ratio to make the kunun-gyada dry powder. Because of the high oil content, the product was determined to have a high crude fat percentage of 24.97 percent. Consumer sensory evaluations gave the product a low overall acceptability rating (2.78) on a 5-point hedonic scale. The powder was found to be quite greasy, which may have influenced the panelists' overall opinion of the product. The goal of this research was to improve the acceptability of dry kunun-gyada.

Powder by adding maltodextrin to disguise the product's oiliness, as well as the effect of three months of storage time on the stability and consumer acceptance of the modified powder (with 5\% maltodextrin added) in comparison to the control (the original kunungyada dry powder without maltodextrin added). Maltodextrin is a polysaccharide used in the food industry. It's made from partially hydrolyzed starch and comes in the form of a white hygroscopic spraydried powder (IPFS, 2018; Revolvy.com, 2018). It's anutritive saccharide polymer made uplargely of Dglucose units linked by [(]-4 bonds with a dextrose equivalent (D.E.) ofless than 20 (Wang \& Wang 2000). 
It is easily digested and is absorbed at the same rate as glucose (CFR, 2018). It is commonly used in food goods as a flavor carrier as well as to increase thickness and texture (Clean lab, 2018; Wang \& Wang, 2000). Villagran (2015) found that adding maltodextrin to food can have a masking effect on oiliness or encapsulation, which can also be referred to as dilution of oiliness in food because the oiliness is not reduced in quantity but hidden by maltodextrin to increase acceptance. Fat in food contributes to flavor and mouthfeel, but it can also cause oiliness, which might decrease a consumer's willingness to eat it. Maltodextrin is also used in foods to transform oily or liquid substances into powders for convenience (Livestrong.com, 2018). Maltodextrin can also be utilized to improve the quality of food products, according to studies. When 30 percent maltodextrin was added to spray-dried honey jackfruit powder, Wong and Tan (2017) reported a high yield of 66.90 percent and good powder properties in terms of water activity, solubility, moisture content, hygroscopicity, bulk density, and color. Maltodextrin is a drying agent that can also be employed to transport health-promoting substances (Vidovi et al., 2014). Adding 10\% maltodextrin to Satureja Montana dry powder extract resulted in the highest levels of total phenols, total flavonoids, and antioxidant activity. However, the sensory evaluation revealed that as the maltodextrin concentration rises, the powder acceptability rises as well (Vidovi et al., 2014). Maltodextrin has been studied extensively as a fat substitute as well as a drying aid (Hedayatnia and Mirhosseini, 2018; Colla et al., 2018; Khan et al., 2018; Kiritsakis et al., 2018; Marte et al., 2018). However, there has been little research on the use of maltodextrin in the reduction of oiliness (Villagran, 2015; Livestrong.com, 2018).

\section{MATERIALS AND METHODS 2.1 Materials}

Maltodextrin (Brand AAA, DE 10) was from San Soon Seng Food Industries Sdn. Bhd. (Sungai Buloh, Malaysia). Aluminum-laminated polyethylene (ALP) pouches $(18 \times 9 \mathrm{~cm})$ with a thickness of $86 \mu \mathrm{m}$ were purchased from Good and Well Sdn. Bhd. (Selangor, Malaysia).

\subsection{Preparation of ready-to-consume kunun gyada powder}

Dry kunun gyada powder was prepared from a mixture of groundnut paste, rice flour, 24-hour germinated soybean flour, and roasted sesame seed flour at a ratio of 60:25:10:5. The mixture was then made into a slurry. The slurry was drum-dried at a drum dryer temperature of $100{ }^{\circ} \mathrm{C}$, the pressure of 3 bars, and drum rotation of $2 \mathrm{rpm}$ as reported by Laryea et al. (2018) with some modification. After cooling, the dry flakes were ground into powder using a home blender (Pensonic Model PB-3205DJ, Malaysia).

\subsection{Addition of maltodextrin}

The dry kunun gyada product was weighed (95 g) and $5 \mathrm{~g}$ maltodextrin of DE 10 was added. The control sample had no maltodextrin added. The powder was then mixed using a home blender and subjected to sensory evaluation. After sensory evaluation, the modified kunun gyada powder with $5 \%$ maltodextrin together with the control (without maltodextrin) was packed where 50 grams each were placed in aluminumlaminated polyethylene (ALP) pouches $(18 \times 9 \mathrm{~cm})$ with a thickness of $86 \mu \mathrm{m}$ purchased from Good and Well Sdn. Bhd. (Selangor, Malaysia), flushed with nitrogen gas before heat-sealing at $150 \pm 1{ }^{\circ} \mathrm{C}$ using a vertical continuous band sealer (GW-FRB-980II, Good and Well, Selangor, Malaysia). The packages were stored at room temperature $25 \pm 2{ }^{\circ} \mathrm{C}$ and relative humidity of 41 $\pm 2 \%$ for 3 months. The analysis was conducted before and after storage which included determination of oiliness by sensory evaluation, moisture content, colour, peroxide value, the viscosity of the reconstituted product, and product acceptability.

\subsubsection{Determination of oiliness (by a sensory evaluation) before and after storage}

The sensory evaluation for the oiliness of the control and the product with $5 \%$ maltodextrin was evaluated before and after storage based on a 5-point hedonic scale by 30 panelists (Nigerian UPM postgraduate students) who are familiar with the product.

\subsubsection{Determination of moisture content and water activity before and after storage}

The moisture content before and after the storage of the samples was determined according to AOAC standard method (2005). The water activity $\left(\mathrm{a}_{\mathrm{w}}\right)$ was determined using a water activity analyzer (Model TE8309, Aqua Lab, USA). The instrument was first turned on to warm for about 1 hour, then calibrated using calibration standard solution of sodium chloride $(\mathrm{NaCl})$ to obtain an $\mathrm{a}_{\mathrm{w}}$ of 0.76 and potassium chloride $(\mathrm{KCl})$ to obtain an $\mathrm{a}_{\mathrm{w}}$ of 0.85 . One gram $(1 \mathrm{~g})$ of dry powder was placed in the sample dish with a sample capacity of $7.5 \mathrm{ml}$ and inserted into the water activity meter. The machine automatically reads the water activity of the sample. The reading was displayed on the screen and expressed as $\left(\mathrm{a}_{\mathrm{w}}\right)$ measured at a temperature of $25 \pm 2{ }^{\circ} \mathrm{C}$.

\subsubsection{Determination of colour before and after storage}

The colour of the control and sample with $5 \%$ maltodextrin was determined before and after storage using a Minolta CR-410 chromo meter (Model B8408908) coupled with a Minolta DP-400 data processor (Model B2014888 Konica Minolta, Japan).

\subsubsection{Determination peroxide value before and after storage}

The peroxide value of the control and sample with $5 \%$ maltodextrin kunun gyada power was determined before and after storage using the method described by AOCS (1989). Five (5 g) of kunun gyada 
powder sample was weighed into a conical flask containing $30 \mathrm{ml}$ of acetic acid-chloroform solution (3:2 $\mathrm{v} / \mathrm{v})$ and swirled to dissolve the sample. Saturated potassium iodide solution $(0.5 \mathrm{ml})$ was then added and allowed to stand with occasional shaking for 1 minute. This was followed by the addition of $30 \mathrm{ml}$ of distilled water. The mixture was then titrated with $0.1 \mathrm{~N}$ sodium thiosulfate with constant agitation until the yellow iodine colour has almost disappeared. Then $0.5 \mathrm{ml}$ of $0.5 \%$ starch indicator solution was added and titration was continued drop-wise until the blue-grey colour disappears indicating the titration endpoint. A blank test without sample was also conducted and the peroxide value was calculated using the following equation (Eq. 4.1):

$\mathrm{PV}=\frac{(\mathrm{Vs}-\mathrm{Vb}) \mathrm{N} \times 1000}{\mathrm{~W}}$, express in $\mathrm{meq} / \mathrm{kg}$

Where Vs = volume $(\mathrm{ml})$ of sodium thiosulfate used in the titration of the sample, $\mathrm{V}_{\mathrm{b}}=$ volume $(\mathrm{ml})$ of sodium thiosulfate used for the blank titration, $\mathrm{W}=$ weight of sample used, and $\mathrm{N}=$ normality of sodium thiosulfate.

\subsubsection{Determination of viscosity of reconstituted product and product with $5 \%$ maltodextrin}

The viscosity of reconstituted kunun gyada from both the control and product with $5 \%$ maltodextrin was determined according to the method described by Mbaeyi-Nwaoha and Onweluzo (2013) with some modifications. Samples of kunun gyada powder (control) and product with $5 \%$ maltodextrin were reconstituted into porridge using $25 \mathrm{~g}$ each of the sample mixed with $350 \mathrm{ml}$ of boiled water. The porridge was allowed to cool by keeping it at room temperature $25 \pm 2{ }^{\circ} \mathrm{C}$ and viscosity was measured at a rheometer temperature of $25 \pm 2{ }^{\circ} \mathrm{C}$ using a rheometer (Rheolab QC, Anton Paar, Germany) with a measuring bob (diameter of $26.66 \mathrm{~mm} \times$ length $39.99 \mathrm{~mm}$ ) and a measuring cup (28.92 $\mathrm{mm}$ in diameter). A reconstituted porridge sample of $25 \mathrm{ml}$ was poured into the measuring cup and was then attached back to the rheometer. Viscosity was measured at a shear rate of $1550.90 \mathrm{~s}^{-1}$ and expressed as mPas.

\subsection{Product acceptability}

A 5 point hedonic scale was used to evaluate the sensory attributes of the kunun gyada powder for the control product and the product with $5 \%$ maltodextrin. Panelists were required to score the samples from 1 (Dislike Extremely) to 5 (Like
Extremely). Thirty untrained panelists (Nigerian postgraduate students in UPM) who were familiar with the product for over 20 years were each given five different kunun gyada powder. The samples were coded using 3-digit random numbers and randomly served to assess for colour, appearance, texture, and overall acceptability.

\subsection{STATISTICAL ANALYSIS}

All measurements were done in triplicate and values were presented as mean \pm standard deviation of triplicate determination. One-way analysis of variance (ANOVA) was used to identify the significant differences among the means of different samples and the Turkey test was also used to compare the means of the obtained values for the sensory evaluation. A paired T-test was used for values obtained before and after storage to identify the significant differences among the means of samples using the Probability level of $\mathrm{P} \leq$ 0.05 was identified as significant. Values were presented as mean \pm standard deviation of triplicate determination. The statistical analysis was carried out using Minitab version 17 (Minitab Pty Ltd, Sydney).

\section{RESULTS AND DISCUSSION \\ 3.1 Product acceptability evaluation of kunun gyada powder samples \\ The results for the sensory evaluation of the} control and product with $5 \%$ maltodextrin is presented in Table 1. Results obtained indicate that all the sensory attributes assessed (colour, appearance, texture, and overall acceptability) were significantly influenced by the addition of $5 \%$ maltodextrin. The control was scored lower for colour (2.47), appearance (2.21), texture (2.00), and the overall acceptability 2.75, respectively, based on a 5-point hedonic scale. The addition of $5 \%$ maltodextrin could have been the reason for the high overall acceptability score (3.89) for the product with $5 \%$ maltodextrin over the control. The acceptability of the control product was lower and could be because the product was oily. The results show that the addition of $5 \%$ maltodextrin can improve the acceptability of kunun gyada powder. Kothakota et al. (2014) showed that the addition of maltodextrin has improved the sensory properties and overall acceptability of reconstituted spry-dried dahi powder. Similarly, Jittanit et al. (2011) reported that drum dried tamarind powders with added maltodextrin as drying agent was more acceptable in appearance, color, and overall likeness with a higher score than the product with added gum arabic.

Table-1: Mean score (five-point scale) of Sensory attributes for acceptability of control and product with $5 \%$ maltodextrin

\begin{tabular}{|r|r|r|}
\hline Attributes & Control & product with 5 \% maltodextrin \\
\hline Colour & $2.47 \pm 0.02^{\mathrm{b}}$ & $3.20 \pm 0.03^{\mathrm{a}}$ \\
\hline Appearance & $2.21 \pm 0.01^{\mathrm{b}}$ & $3.03 \pm 0.02^{\mathrm{a}}$ \\
\hline Texture & $2.00 \pm 0.02^{\mathrm{b}}$ & $2.95 \pm 0.02^{\mathrm{a}}$ \\
\hline Overall acceptability & $2.72 \pm 0.02^{\mathrm{b}}$ & $3.89 \pm 0.01^{\mathrm{a}}$ \\
\hline
\end{tabular}

Means within the same row having a common superscript are not significantly different $(\mathrm{P} \geq 0.05)$ 
From the analysis of variance, the P-value obtained was 0.00 which is less than the confidence level of 0.05 . This indicates that the amount of maltodextrin added $(5 \%)$ had a significant effect on the overall acceptability of KGP5 at a $95 \%$ confidence level $(\mathrm{P} \leq 0.05)$. The main effect plot also shows that the addition of $5 \%$ maltodextrin to kunun gyada powder had a major effect on the overall acceptability (Figure $1)$.

$\begin{array}{lllccl}\text { Analysis of Variance } & & & & & \\ \text { Source } & \text { DF } & \text { Adj SS } & \text { Adj MS } & \text { F-Value } & \text { P-Value } \\ \text { Amount of maltodextrin (\%) } & 1 & 6.302 & 6.3019 & 20.67 & 0.000 \\ \text { Error } & 88 & 26.826 & 0.3048 & & \end{array}$

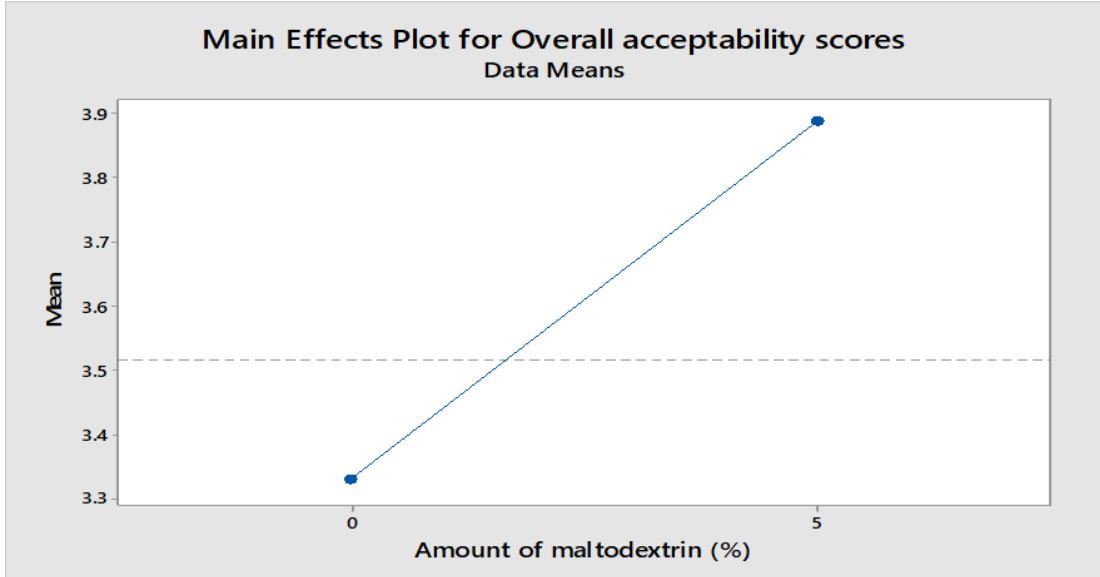

Fig-1: Main effects plot for overall acceptability scores with the addition of $5 \%$ maltodextrin to kunun gyada powder

\subsection{The viscosity of reconstituted kunun gyada powder}

The viscosity of the reconstituted kunun gyada powder for both the control and product with $5 \%$ maltodextrin is presented in Table 2 . The viscosity of kunun gyada has significantly changed with the addition of $5 \%$ maltodextrin. The addition of $5 \%$ maltodextrin increased the viscosity of the control from 15.75-17.12 mPa.s. Jittanit et al. (2011) reported an increase in viscosity of drum dried reconstituted tamarind powders when maltodextrin was added. Grabowski et al. (2008) has shown that during heating, the interaction between maltodextrin and polysaccharides present in sweet potatoes powder may be slightly disrupted and consequently releasing longchain molecules into the solution and slightly increasing the viscosity.

\section{Table-2: The viscosity of reconstituted Kunun gyada powder}

\begin{tabular}{|l|l|}
\hline Sample & Viscosity (mPa.s) \\
\hline Control product & $15.75 \pm 0.02^{\mathrm{b}}$ \\
\hline Product with 5\% Maltodextrin & $17.12 \pm 0.02^{\mathrm{a}}$ \\
\hline
\end{tabular}

Means within the same row having a common superscript are not significantly different $(\mathrm{P} \geq 0.05)$

3.3 Overall acceptability evaluation on oiliness before and after 3 months storage of Kunun gyada powder samples

The evaluation of oiliness on the control and product with $5 \%$ maltodextrin was conducted base on a 5-point hedonic scale before and after 3 months storage at $25{ }^{\circ} \mathrm{C} \pm 2$ and relative humidity of $41 \pm 2 \%$. Results obtained show that the addition of $5 \%$ maltodextrin has improved the acceptability of the product before storage as indicated by a score of 3.38 (Table 3). After the storage period, the product with $5 \%$ maltodextrin was still scored higher than the control which had a lower score of 2.50 . From the p-value $(0.45)$ obtained for the control, the difference in the acceptability score for the control before and after storage (0.06) was significant. This indicates that the control was less acceptable even after storage while the product with $5 \%$ maltodextrin had an acceptability difference of 0.01 after the storage period which is lower than that of the control. This is a good indication that the addition of $5 \%$ maltodextrin has improved consumer acceptability. 
Table-3: Overall acceptability evaluation score of oiliness before and after storage of Kunun gyada powder samples

\begin{tabular}{|r|r|r|r|r|}
\hline Sample & Oiliness before storage & Oiliness after storage & Difference & p-value \\
\hline Control & $2.56 \pm 0.56^{\mathrm{a}}$ & $2.50 \pm 0.50^{\mathrm{a}}$ & 0.06 & 0.45 \\
\hline product with 5\% maltodextrin & $3.38 \pm 0.38^{\mathrm{f}}$ & $3.37 \pm 0.43^{\mathrm{f}}$ & 0.01 & 0.03 \\
\hline
\end{tabular}

Means within the same row having a common superscript are not significantly different $(\mathrm{P} \geq 0.05)$.

Effect of storage on moisture content and water activity of Kunun gyada powder (control) and the powder with $5 \%$ maltodextrin

The moisture contents of the product samples before and after storage are presented in Table 4 . Results obtained indicate that both control and product with $5 \%$ maltodextrin did not record any increase in moisture content during storage. The packaging material was effective in not allowing the product to absorb moisture during storage. The addition of maltodextrin in the powder did not lead to moisture absorption by the product. Brewer, (2012) reported that maltodextrin can be used as a drying agent in food products.

Table-4: The moisture content of Kunun gyada samples before and after storage (\%)

\begin{tabular}{|l|l|l|l|l|}
\hline Sample & Moisture before storage & Moisture after storage & Difference & p-value \\
\hline Control & $6.32 \pm 0.01$ & $6.29 \pm 0.01$ & 0.03 & 0.04 \\
\hline product with 5\% maltodextrin & $6.36 \pm 0.01$ & $6.33 \pm 0.01$ & 0.03 & 0.05 \\
\hline
\end{tabular}

Water activity before and after storage for the samples also indicated that there was no change during the storage period (Table 5). Again, this could be attributed to the effectiveness of the packaging material used.

Table-5: The water activity of Kunun gyada before and after storage (\%)

\begin{tabular}{|l|l|l|l|l|}
\hline & $\begin{array}{l}\text { Water activity before } \\
\text { storage }\end{array}$ & $\begin{array}{l}\text { Water activity after } \\
\text { storage }\end{array}$ & Difference & $\begin{array}{l}\text { p- } \\
\text { value }\end{array}$ \\
\hline Control & $0.57 \pm 0.00$ & $0.56 \pm 0.01$ & 0.01 & 0.01 \\
\hline $\begin{array}{l}\text { product with 5\% } \\
\text { maltodextrin }\end{array}$ & $0.58 \pm 0.00$ & $0.57 \pm 0.01$ & 0.01 & 0.01 \\
\hline
\end{tabular}

3.4 Effect of storage on the colour of control and product with $5 \%$ maltodextrin before and after storage

Results for color $\mathrm{L}^{*}, \mathrm{a}^{*}$, and $\mathrm{b}^{*}$ of the samples are presented in Table 6 . The results for whiteness ( $\left.\mathrm{L}^{*}\right)$ show that the whiteness of kunun gyada powder increased from $66.07 \%$ (control) to $76.31 \%$ when $5 \%$ maltodextrin was added. The increase in whiteness could be due to the color of maltodextrin powder which is white. Caliskan and Dirim, (2013) also reported an increase in whiteness and a decrease in $a^{*}$ and $b^{*}$ for spray-dried sumac extract when maltodextrin was added. Similarly, Nadeem et al. (2011) observed a similar decrease in $a^{*}$ and $b^{*}$ of spray-dried mountain tea added with maltodextrin. The decrease of $0.01 \%$ in $\mathrm{L}^{*}$ for the control after storage was not significant. However, the difference recorded after storage for the product with $5 \%$ maltodextrin $(0.29)$ was significant. The results obtained for redness and yellowness show that the addition of $5 \%$ maltodextrin has decreased the redness from 2.53-2.38 and the yellowness of the product also decreased from 20.98-19.45 \%, respectively. Yousefi et al. (2011) reported a reduction in both $a^{*}$ and $b^{*}$ with the addition of maltodextrin to spray-dried Pomegranate juice. Results also show that there was no significant change in $b^{*}$ for both the control and $5 \%$ added maltodextrin samples at the end of storage.

Table-6: Colour parameter $\left(\mathrm{L}^{*}, \mathrm{a}^{*}\right.$ and $\left.\mathrm{b}^{*}\right)$ of kunun gyada powder samples before and after storage (\%)

\begin{tabular}{|l|l|l|l|l|}
\hline Sample & L* $^{*}$ before storage & After storage & Difference & p-value \\
\hline Control product & $66.07 \pm 0.08$ & $66.06 \pm 0.08$ & 0.01 & 0.65 \\
\hline Product with Maltodextrin (5\%) & $76.31 \pm 0.02$ & $76.02 \pm 0.02$ & 0.29 & 0.00 \\
\hline & $\mathrm{a}^{*}$ before storage & After storage & Difference & $\mathrm{p}$-value \\
\hline Control & $2.53 \pm 0.01$ & $2.51 \pm 0.01$ & 0.01 & 0.09 \\
\hline Product with Maltodextrin (5\%) & $2.38 \pm 0.01$ & $2.30 \pm 0.01$ & 0.08 & 0.05 \\
\hline & $\mathrm{b}^{*}$ before storage & After storage & Difference & $\mathrm{p}$-value \\
\hline Control & $20.98 \pm 0.02$ & $20.90 \pm 0.03$ & 0.08 & 0.16 \\
\hline Product with Maltodextrin $(5 \%)$ & $19.45 \pm 0.07$ & $19.39 \pm 0.06$ & 0.06 & 0.89 \\
\hline
\end{tabular}




\subsection{Peroxide value (PV) of kunun gyada powder and product with $5 \%$ maltodextrin before and after storage}

There was no change in the peroxide value for the control. Product with $5 \%$ maltodextrin had a difference of 0.01 after storage (Table 7). This shows that both the products were stable to oxidation during the storage period because the peroxide value did not increase for the control during the storage period and a difference of 0.00 was recorded. The PV for the sample with $5 \%$ maltodextrin had an increase of 0.01 which was also low and the PV value was within the acceptable limit, less than $10 \mathrm{mEq} / \mathrm{kg}$ (Gunstone, 2008). The stability of the products during the storage period could also be attributed to packaging material which prevented the diffusion of oxygen or absorption of moisture and penetration of sunlight into the package and flushing of the product with $\mathrm{N}_{2}$ before the package was sealed.

Table-7: Peroxide value (PV) of kunun gyada samples before and after storage $(\mathrm{mEq} / \mathrm{kg})$

\begin{tabular}{|l|l|l|l|l|}
\hline Sample & PV before storage & PV after storage & Difference & p-value \\
\hline Control product & $0.10 \pm 0.01$ & $0.10 \pm 0.01$ & 0.00 & 0.004 \\
\hline Product with Maltodextrin (5\%) & $0.11 \pm 0.01$ & $0.12 \pm 0.01$ & 0.01 & 0.003 \\
\hline
\end{tabular}

\section{CONCLUSION}

Maltodextrin was added to kunun gyada powder to improve its oiliness. An investigation was conducted before and after the storage for the control product (without maltodextrin) and the product with 5 $\%$ maltodextrin for 3 months. It was concluded that the addition of $5 \%$ maltodextrin to the kunun gyada powder had improved the oiliness of the product to dryness and was scored high by panelists based on sensory assessment. The colour, moisture content, water activity, and peroxide value of both the control and product with $5 \%$ maltodextrin were stable during the storage period of 3 months. This shows that the use of 5 $\%$ maltodextrin in this study to improve the oiliness (increase dryness of oily kunun gyada powder) and also increase the acceptability of the oily product was possible.

\section{REFERENCES}

- AOAC International. (2005). Official Methods of Analysis of AOAC International (18 ${ }^{\text {th }}$ Ed.). Gathersburg, MD, USA: Association of Analytical Communities.

- $\quad$ AOCS (1989) Official Methods and Recommended Practices of the American Oil Chemists' Society, $4^{\text {th }}$ ed, ed. D. Firestone, AOCS, Champaign

- Brewer, M. S. (2012). Reducing the fat content in ground beef without sacrificing quality: A review. Meat Science, 91(4), 385-395.

- Caliskan, G., \& Dirim, S. N. (2013). The effects of the different drying conditions and the amounts of maltodextrin addition during the spray drying of sumac extract. Food and Bioproducts Processing, 91(4), 539-548.

- CFR (2018). Code of Federal Regulations, U.S. Food, and Drug Administration. Direct food substances affirmed as generally recognized as safe. Revised as of April 1, 2018 [CITE: 21CFR184.1444] Title 21, Volume 3.

- Clean label.com. What is maltodextrin? https://gocleanlabel.com/what-is-maltodextrin/ Retrieved on 6 December 2018.

- Colla, K., Costanzo, A., \& Gamlath, S. (2018). Fat
Replacers in Baked Food Products. Foods, 7(12), 1-12.

- Gaffa, T., Jideani, I. A., \& Nkama, I. (2002). Traditional production, consumption, and storage of Kunu-a nonalcoholic cereal beverage. Plant Foods for Human Nutrition, 57(1), 73-81.

- Grabowski, J. A., Truong, V. D., \& Daubert, C. R. (2008). Nutritional and rheological characterization of spray-dried sweet potato powder. LWT-Food Science and Technology, 41(2), 206-216.

- Gunstone, F. D. (2008). Disappearance. Lipid Technology, 20(2), 48-48.

- Hedayatnia, S., \& Mirhosseini, H. (2018). Quality of Reduced-Fat Dairy Coffee Creamer: Affected by Different Fat Replacer and Drying Methods. In Descriptive Food Science. IntechOpen.115-135.

- IPFS.

Maltodextrin. https://en.wikipedia.org/wiki/Maltodextrin. Retrieved on 31 December 2018.

- Jittanit, W., Chantara-In, M., Deying, T., \& Ratanavong, W. (2011). Production of tamarind powder by drum dryer using maltodextrin and Arabic gum as adjuncts. Songklanakarin Journal of Science and Technology, 33(1), 33-41.

- Khan, S., Rustagi, S., Choudhary, S., Pandey, A., Kamran, M., Khan, A. K., \& Singh, A. (2018). Sucralose and maltodextrin-An alternative to lowfat sugar-free ice-cream. Bioscience Biotechnology Research Communications, 11(1), 136-143.

- Kiritsakis, K., Goula, A. M., Adamopoulos, K. G., \& Gerasopoulos, D. (2018). Valorization of Olive Leaves: Spray Drying of Olive Leaf Extract. Waste and Biomass Valorization, 9(4), 619-633.

- Kothakota, A., Kumar, A., Kumar, M., Juvvi, P., Rao, S., \& Kautkar, S. (2014). Characteristics of spray-dried dahi powder with maltodextrin as an adjunct. International Journal of Agriculture, Environment and Biotechnology, 7(4), 849-865.

- Laryea, D., Wireko-Manu, F. D., \& Oduro, I. (2018). Effect of Drum Drying on the Colour, Functional, and Pasting Properties of Sweetpotatobased Complementary Food.

- Livestrong.com (2018). Why use Maltodextrin in 
foods. https://www.livestrong.com/article/447600why-use-maltodextrin-in-food/ Retrieved 31th December 2018.

- Marte, Y. A., Marte, Y. A., Tejada, A. E., \& Berruezo, G. R. (2018). Effect of different concentrations of pulverized mesocarp of Citrus paradisi Mac. on the bromatological characteristics of spray-dried lemon juice powder. Food Science and Nutrition, 6(5), 1261.

- Mbaeyi-Nwaoha, I.E., \& J.C. Onweluzo (2013) Functional properties of Sorghum (S. bicolor $L)$ Pigeonpea (Cajanus cajan) flour blends and Storage Stability of Flaked Breakfast formulated from blends. Pakistan Journal of Nutrition. 12 (4):382397

- $\quad$ Nadeem, H. Ş., Torun, M., \& Özdemir, F. (2011). Spray drying of the mountain tea (Sideritis stricta) water extract by using different hydrocolloid carriers. LWT-Food Science and Technology, 44(7), 1626-1635.

- Revolvy.com. (2018). Maltodextrin. https://www.revolvy.com/page/Maltodextrin. Retrieved on 31 December 2018.
- Vidović, S. S., Vladić, J. Z., Vaštag, Ž. G., Zeković, Z. P., \& Popović, L. M. (2014). Maltodextrin as a carrier of health beneficial compounds in Satureja Montana dry powder extract obtained by spray drying technique. Powder Technology, 258, 209-215.

- Villagran, M. D. M. S. (2015). U.S. Patent Application No. 14/260,257.

- Wang, Y. J., and Wang, L. (2000). Structures and properties of commercial maltodextrins from corn, potato, and rice starches. Starch-Stärke, 52(8-9), 296-304.

- Wong, C. W., \& Tan, H. H. (2017). Production of spray-dried honey jackfruit (Artocarpus heterophyllus) powder from enzymatic liquefied puree. Journal of Food Science and Technology, 54(2), 564-571.

- Yousefi, S., Emam-Djomeh, Z., \& Mousavi, S. M. (2011). Effect of carrier type and spray drying on the physicochemical properties of powdered and reconstituted pomegranate juice (Punica Granatum L.). Journal of Food Science and Technology, 48(6), 677-684.

Cite This Article: Musa Halilu, Yunusa Bello M, Hasanah M. Ghazali (2022). Consumer Preference and Storage Stability Assessment of Drum Dried-Maltodextrin Added Kunun-gyada Powder. EAS J Nutr Food Sci, 4(1), 1-7. 